\title{
The Effcet of Food Volume on Feed Consumption, Feed Conversion and Growth Performance of Fayoumi Chicks
}

\author{
M.I. El Kotoury, G.A.R. Kamar, K.A.O. Yamany and \\ M.M. El Hindawy \\ Department of Animal Production, Faculty of Agricultire, \\ Cairo and Zagazig Universities, Egypt.
}

THis work was conducted to study the effect of feed volume on feed 1 onsumption, feed conversion, growth performance and the economical efficiency of feed utiliation of Fayoumi chicks as lical breed,

166 Fagumi chicks of two weeks ol 1 were divided randomly into three groups $\mathrm{A}, \mathrm{B}$ and $\mathrm{C}$ of $55,55,56$ chicks / each, respectively.

Rations were formulated from the available ingredients prevailing in Egypt. All the experimental rations were nearly isocaloric $(2768-2807 \mathrm{Kscal} / \mathrm{M} . \mathrm{E} . \mathrm{kg})$ and isonitrogenous $(18.17-18.86$ crude protein), but the difference was in volume and densily as follows:

\begin{tabular}{c|c|c|c}
\hline Groups & A & B & C \\
\hline Volume CC/mg. . . & 1.48 & 1.72 & 1.90 \\
Density g/CC . . . & 0.68 & 0.58 & 0.53 \\
\hline
\end{tabular}

Birds were weighed individually and feed consumption was recorded per each group at weekly interval up to 18 weeks. Results obtained can be summarized as follows:

- Birds fed on larger volume of rations consumed more feed than that fed smaller volume of ration. The increase in food consumption by Fayoumi Chicks which fed on ration B $(1.72 \mathrm{CC} / \mathrm{g})$ and $\mathrm{C}(1.90 \mathrm{CC} / \mathrm{g})$ represented $12.3 \%$ and $21.0 \%$ relatively to that consumed by chicks fed on ration $\mathrm{A}(1.48 \mathrm{CC} / \mathrm{g})$.

- Feed converstion of the birds which fed on compact ration were better than that fed on coarser and bulkey rations. Feeding bulky feed required consequently more energy and more protein for one gain weight unit while the compact food required less in this respect.

- The birds which fed on ration A gave more gain in weight than that fed on rations $B$ and $C$.

- The relative growth rate values for groups during the experimental priod (2-18 weeks)were $177.3,176.4$ and $175.1 \%$ for groups $\mathrm{A}, \mathrm{B}$ and $\mathrm{C}$, respectively.

- From the economical point of view, one unit gain in weight for birds fed on ration $\mathrm{A}$ saves 18.0 and $36,4 \%$ than that fed on ration $\mathrm{B}$ and $\mathrm{C}$, respectively.

Generally speaking, it, could be concluded that feeding Fayo. umi chicks on compact rations may be, not only more favo:rable for bird's growth, but also more economical use than feeding bulky food. 
The chemical analysis of poultry feed-stuffs do not give an accurate picture about the biological value of these feeds. Other measurements should be taken into consideration, hence the physical properties of the feeding ingredients or ration could also be of great value.

In Egypt there are many feed-stuffs which differ greatly in their physical properties (volume $\mathrm{CC} / \mathrm{g}$ and density $\mathrm{g} / \mathrm{CC}$ ). Studying the effect of physical properties on some productive traits may be of great berefit in poultry rations.

In this work, the effect of food volume on feed consumption, feed conversion and growth performance of Fayoumi chicks were studied.

\section{Material and Methods}

This work was carried out in the Poultry Farm, Faculty of Agriculture, Zagazig University, during 1974.166 Fayoumi chicks of two weeks old nearly similar in their live weight were used in this study. The birds were divided into three groups, A,B and $\mathrm{C}$ of 55,55 and 56 in each, respectively. All the birds were wingbanded to obtain individual records. All birds were reared and treated under the same managerial and environmental conditions, in total confinement house keeping system of floor breeding rooms. Waterers, feeding troughs, electric heaters, deep wheat straw litter and good ventilation were provided.

The experimental rations were formulated from the available ingredients prevailing in Egypt as shown in Table 1.

The volume of experimental rations expressed as $\mathrm{CC} / \mathrm{g}$ and density as $\mathrm{g} / \mathrm{CC}$ were estimated from random samples and the average of 5 estimates. was recorded. The volume $\mathrm{CC} / \mathrm{g}$ was measured by lightly pouring 100 of rations into a graduated cylinder. The ration volume was increased by coarse wheat bran and protein.

The chemical analysis of experimental rations for groups followed the ordinary conventional methods of A.O.A.C. 1965 are shown in Table 2.

All rations were nearly equal in the estimated crude protein, metabolizable energy, other extract and energy protein ratio, but these rations were differed in their volume $\mathrm{CC} / \mathrm{g}$ and density $\mathrm{g} / \mathrm{CC}$ as shown in Table 2.

The birds were weighed, individually, at weekly intervals up to 18 weeks, by Mettlar balance to the nearest $\mathrm{g}$ at $8 \mathrm{a} . \mathrm{m}$. absolute and relative gain were also calculated according to Brody (1949).

$$
\text { Reiative growth rate }=\frac{1 / 2(\mathrm{~W} 1+\mathrm{W} 2)}{\mathrm{W} 2-\mathrm{W} 1} \times 100
$$

The food intake was recorded from the difference between the offered and the rest food after $24 \mathrm{hr}$ to the nearest g. Food conversion was calculated for each experimental groups as number of $\mathrm{kg}$ ration required to one $\mathrm{kg}$ growth T.D/N was calculated in the usual manner, and metaboliable energy were thereafter, calculated according to Rabsts and Morimoto (1965), M. E. $/ \mathrm{k}$. cal. $/ 100 \mathrm{~g}=3.23 \times \mathrm{T} \mathrm{D} \mathrm{N})+27.1$. Energy /protein ratio was also calculated according to Eomies equation, (1962) :

$\mathrm{C} / \mathrm{P}=\frac{\mathrm{k} \text { cal. } \mathrm{M} \cdot \mathrm{E} \cdot \mathrm{Eg} \text { food }}{\% \text { crude }}$

The statistical analysis was performed after Stiedecor ${ }_{\text {(1967) }}$

Egypt. J. Anim. Prod. 17, No. 1 (1977) 
TABLE 1. The formula of the experimental rations.

\begin{tabular}{|c|c|c|c|}
\hline \multirow{2}{*}{ Ingredients } & \multicolumn{3}{|c|}{ Groups } \\
\hline & A & B & C \\
\hline & $\%$ & $\%$ & $\%$ \\
\hline $\begin{array}{l}\text { Ground yellow corn . . . } \\
\text { Grashed rise } \\
\text { Coarse wheat bran. } \\
\text { Protelau } \\
\text { Dec. cotton seed meal } \\
\text { Fish meal } \\
\text { Bone meal } \\
\text { Ground limestone . . . . . } \\
\text { Sodium chloride } \\
\text { Mineral mixture, }\end{array}$ & $\begin{array}{l}50 \\
15 \\
10 \\
15 \\
7 \\
2 \\
0.5 \\
0.3 \\
0.2\end{array}$ & $\begin{array}{r}50 \\
10 \\
5 \\
10 \\
15 \\
7 \\
2 \\
0.5 \\
0.3 \\
0.2\end{array}$ & $\begin{array}{l}55 \\
\frac{55}{10} \\
10 \\
15 \\
7 \\
2 \\
0.5 \\
0.3 \\
0.2\end{array}$ \\
\hline 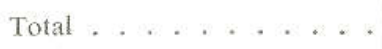 & 100 & 100 & 100 \\
\hline
\end{tabular}

Feed additives:

$$
\begin{aligned}
& 0.5 \% \text { yeast } \\
& 0.5 \% \text { vit } A+d_{3} \text { (Each } g \text { contains } 5000 \text { IU vit } A \text { and } 500 \\
& 1 U \text { vit } D_{3} \text { ) }
\end{aligned}
$$

TABLE 2. Chemical and physical analysis of the experimental rations.

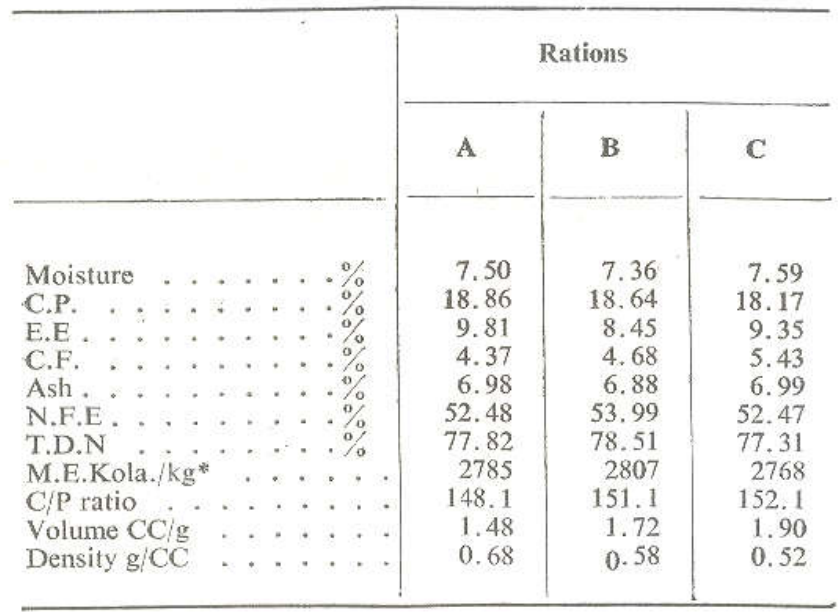

- Estimated according to Kabota and Morimoto equation (1965).

Egypt. J. Anim. Prod. 17, No. 1 (1977) 
Effect of food volume on feed consumption and conversion

The average values of feed consumption per bird for different ages of Fayoumi chicks during the experimental period from 2 to 18 weeks old are
shown in Table 3.

TABLE 3. The average values of feed consumption per bird for different ages of Fayoumi chicks.

\begin{tabular}{c|r|r|r|r|r|r}
\hline Group & \multicolumn{3}{|c|}{ A } & \multicolumn{2}{|c|}{ B } & \multicolumn{2}{c}{ C } \\
\cline { 2 - 6 } $\begin{array}{c}\text { Age in } \\
\text { weeks }\end{array}$ & F.C./g & Relative & F.C./g & Relative & F.C./g & Relative \\
\hline 2-8 & 833.7 & 100 & 999.6 & 119.6 & 1090.6 & 130.8 \\
$2-12$ & 1190.7 & 100 & 1360.8 & 114.3 & 1476.3 & 124.0 \\
$12-18$ & 2899.5 & 100 & 3124.8 & 109.3 & 3343.2 & 116.0 \\
$2-18$ & 4883.9 & 100 & 5485.2 & 112.3 & 5910.1 & 121.0 \\
\hline
\end{tabular}

F.C. $=$ Feed consumed

It is evident that birds in groups $\mathrm{B}$ and $\mathrm{C}$ which were fed rations of larger volume, consumed more feed than that of group $\mathrm{A}$ which were fed smaller volume ration. The increase in feed consumed of groups B and C, represented $12.3 \%$ and $21.0 \%$ more than that relatively to group A. Generally speaking we can say that the increase in feed volume caused a considerable increase in feed consumption. These results were in agreement with those obtained by Gleaves et al. (1963 and 1968), Gleaves and Satyavan (1971) and Deader (1972).

However, there was an assumption that the rapid passage of large volume food could not enable the digestive tract to get use of th: protien or energy needs of the birds. The digestion of the small particles of larger surface may be more easier than that of larger size and smaller surface. So, more food should be taken by the bird because of the faster rate cf passage of big volume and the incomplete digestion of its larger particles, in order to meet its needs.

Effect of feed volume on feea conversion

Results concerning feed conversion of different groups of Fayoumi chicks during the experimental period are shown in Table 4.

Egypt. J. Anim. Prod. 17, No. 1 (1977) 
TABLE 4. Feed conversion of different groups of Fayoumi chicks during the experimental period.

\begin{tabular}{c|c|c|c}
\hline Group & A & B & C \\
\cline { 1 - 2 } Age in weeks & & & \\
\cline { 1 - 2 } $2-8$ & 3.006 & 4.513 & 5.256 \\
$8-12$ & 4.299 & 5.417 & 5.801 \\
$12-18$ & 7.579 & 7.659 & 8.873 \\
$2-18$ & 5.242 & 6.228 & 7.045 \\
\hline
\end{tabular}

The most noticeable trend from these results is the superiority of group A. (which fed compact ration) than the other two groups (which fed bulky rations), in feed conversion throughout the whole period of the study.

Furthermore, the feed conversion by group B which fed relatively more compact ration, was better than that of group $\mathrm{C}$ which fed coarser and more bulky ration.

It was noteworthy that the feed conversion was indirectly affected by gain weight and growth rate. It could be concluded that feeding bulky food, required consequently more energy and more protein for one gain weight units, while compact food required less in this respect. The finding obtained in the study were in agreement with those reported by Heuser and Roblee (1962), and Daader (1972).

Effect of food volume on growth performance

Effect of food volume on live body weight

Average live body weight of different groups at different ages of Fayoum: chicks are shown in Table 5 .

It is noticed that birds of ration $\mathbf{A}$ (compact) was in favour to be heavier in live bcdy weight than birds of both rations B and C (bulky rations) either in males or in females during experimental period. At the end of the experimental pericd, it is nct:ced that the difference in live body weight between group A was higher than that of group B and C, while this difference was very narrow between group $\mathrm{B}$ and $\mathrm{C}$, especially in females.

From the previous results it may be concluded that the live body weights, were affected by the volume of the diet.

Egypt. J. Anim. Prod. 17, No. 1 (1977) 
TABLE 5. Aprage live weights of different groups at different ages of Fayoumi chicks.

\begin{tabular}{|c|c|c|c|c|c|c|}
\hline \multirow{2}{*}{$\begin{array}{c}\text { Group age in } \\
\text { weeks }\end{array}$} & \multicolumn{2}{|c|}{ A } & \multicolumn{2}{|c|}{ B } & \multicolumn{2}{|c|}{ C } \\
\hline & male & Female & Male & Female & Male & Female \\
\hline & $\mathrm{g}$ & $\mathrm{g}$ & $g$ & $\mathrm{~g}$ & $\mathrm{~g}$ & $\mathrm{~g}$ \\
\hline 2 & 61.1 & 57.2 & 60.2 & 56.5 & 56.9 & 56.0 \\
\hline 8 & 337.5 & 335.8 & 296.6 & 263.0 & 274.6 & 252.8 \\
\hline 12 & 621.9 & 605.4 & 561.0 & 501.0 & 540.4 & 496.5 \\
\hline 18 & 1072.0 & 909.8 & 1042.9 & 835.1 & 976.6 & 813.9 \\
\hline
\end{tabular}

Effect of food volume on live gain weight

Results of inve gain weight of different groups at different ayes of chicks are shown in Table 6.

TABLE 6. Live gain weight of different groups at different ages of Fayoumi chicks.

\begin{tabular}{|c|c|c|c|c|c|c|}
\hline \multirow{2}{*}{$\begin{array}{c}\text { Groups age in } \\
\text { weeks }\end{array}$} & \multicolumn{2}{|c|}{ A } & \multicolumn{2}{|c|}{ B } & \multicolumn{2}{|c|}{ C } \\
\hline & Males & Females & Males & Females & Males & Females \\
\hline & $\mathrm{g}$ & g & $\mathrm{g}$ & $\mathrm{g}$ & $\mathrm{g}$ & $\mathrm{g}$ \\
\hline & 275.9 & 278.6 & 236.4 & 205.5 & 217.7 & 196.8 \\
\hline $8-12$ & 284.4 & 269.6 & 264.4 & 238.0 & 265.8 & 243.7 \\
\hline \multirow{2}{*}{$\begin{array}{r}12-18 \\
2-18\end{array}$} & 450.1 & 304.4 & 481.9 & 334.1 & 436.2 & 317.4 \\
\hline & 1010.4 & 852.6 & 982.7 & 778.6 & 919.7 & 757.9 \\
\hline
\end{tabular}

From the previous table it may be reasonable that ihe compact ration A was more suitable to give gain when it may compared with either ration B or ration $\mathrm{C}$ (bulky).

Furthermore, it was noticed that group A gave a higher gain in both maies and females than that of groups B and C.

The analysis of variance for live gain weight data throughout the experimental period at weekıy intervals between groups and sex showed significant difference between groups at all ages except at 9,11 , and 13 weeks of age which were not significant. The data showed significant difference (P 0.05 ) between sex at 4 and 5 weeks and highly significant difference (P 0.01$)$ at ali, weeks of age up to the end of the experiment.

Egypt. J. Anim. Prod. 17, No. 1 (1977) 


\section{Ejgect of food volume on relative srowth rate}

The results concerning relative growth rate of different groups at dif . ferent ages are represented in Table 7.

TABLE 7. Relative growth rate of different groups at different ages.

\begin{tabular}{c|r|r|r|r|r|r}
\hline \multirow{2}{*}{$\begin{array}{c}\text { Groups Age } \\
\text { in weeks }\end{array}$} & \multicolumn{2}{|c|}{ A } & \multicolumn{2}{c|}{ B } & \multicolumn{2}{c}{ C } \\
\cline { 2 - 7 } & Males & Females & Males & Females & Males & Females \\
\hline $2-8$ & $\%$ & $\%$ & $\%$ & $\%$ & $\%$ & $\%$ \\
$8-12$ & 138.3 & 141.8 & 132.6 & 129.2 & 131.3 & 127.5 \\
$12-18$ & 59.3 & 57.3 & 61.7 & 62.3 & 65.2 & 65.0 \\
$2-18$ & 53.1 & 40.2 & 60.1 & 50.0 & 57.5 & 48.4 \\
\hline & 178.3 & 176.3 & 178.2 & 174.6 & 178.0 & 174.3 \\
\hline
\end{tabular}

From these data it could be concluded that the relative growth rate of group $\mathrm{A}$ (which fed compact ration) was more than that of groups B and C (wbich fed bulky rations).

Generally speaking it could be concluded that the compact ration was in favour to better growth performance than that of rations $B$ and $C$ (bulky rations). It is noticed also that the relative increace in food volume resulted in a reversible effect on growth performance of Fayoumi chicks. However, these results are in line with these obtaind by Gieaves et al. (1968), Gleavesand Satyaban (1971) and Daader (1972).

Effect of feed volume on economical efficiency of food

Price/ton/L.E., feed efficiency (kg ration/1000 kg growth) and economical efficiency $(1000 \mathrm{~kg}$ growth/L.E.) of Fayoumi chicks are shown in Tabıe 8.

The values of relative economicai efficiency may clarify more accurately the great margine in costs of unit gain of group A which may save 18.8 and $36.4 \%$ of the costs required to this unit gain compared with ration $\mathrm{B}$ and $\mathrm{C}$, respectively of Fayoumi chicks.

From the previous results, it could be concluded that feeding Fayoumi chicks on compact ration may be, not only more favourable for bird growth but also of more economical use than feeding bulky food.

Egypt. J. Anim. Prod. 17, No. 1 (1977). 
TAE 8. Price / ton / L.E. feed efficiency ( $\mathrm{kg}$ ration / $1000 \mathrm{~kg}$ growth and economical efficiency $1000 \mathrm{~kg}$ growth / L. E. ) of Fayoumi chicks.

\begin{tabular}{|c|c|c|c|}
\hline \multirow{2}{*}{ Item } & \multicolumn{3}{|c|}{ Groups } \\
\hline & A & B & C \\
\hline Price / ton / L.E. . . . . . . . & 45.8 & 45.8 & 46.5 \\
\hline Feed efficiency ( $\mathrm{kg}$ ration / $1000 \mathrm{~kg}$ growth & 5242 & 6228 & 7045 \\
\hline Costs of $1000 \mathrm{~kg}$ growth / L.E. . . . . & 240.1 & 285.2 & 327.6 \\
\hline Relative costs . . . . . . . & 100.0 & 118.8 & 136.4 \\
\hline Relative economical efficiency $\% \ldots$. & 100.0 & 81.2 & 63.6 \\
\hline
\end{tabular}

References

A.O.A.C. ( 1965) "Oficial Methods of Anaiysis of Association of Official Agricuiture Chemists" 8 th ed. published by the A.O.A.C. Washington.

Brody, S. (1949) "Bioenergetics and Growth". New York Reinheld Co.

Combs, G.F. (1962) "The interrelation Ships of dietary energy and protein in poultry nutritiot. "Nutrit ' $n$ of Pigs and Poulty' Ed. by J.T. Morgan and D. Lewis. London : Butterworths. (Cited after Bolton, W. of England Vol. 126, 206 - 220).

Daader, A.H. ( 1972 ) The effect of feed bukliness and fibre level on the digestive tract of the chick. Msc. Thesis, Ain-Shams University.

Gleaves, E.W. and Satyavan, D. (1971) The influence of dietary and environmental factors upon feed consumption and production responses in laying chicks. Poultry Sci., 50, 46.

_-_ Tonkinson, L.V. Dunkelgod, K.E., Theyer, R.H. Sirny, R.J. and Morrisen, R.D. (1963) Regulating nutrient intake in laying hens with diets fed cdlibitum. Poultry Sci., $4 \%, 363$.

- - Walf, J.D., Harman, C.J., Theyer, R.H. and Morrison, R.D. (1968) The action and interaction of physiological food intake regulators in the laying hen 1- Effect of dietary factors upon feed consumption and production responses. Poultry Sci., 4 \%, 38 .

Heuser, N. and Robler, A.R. ( 1962$)$ Effect of pelleting on the utilization of feed by the growing chicks. Poultry Sci. $41,1489$.

Kabota, D. and Morimoto, H. (1965) Nutritive value of feedstuffs for poultry and reliability of digestible nutrients formulas feeds calculated from the digestible protein and T.D.N., contents of ingredients. J. Poultry Sci., \%, 63 .

Snedecor, G.W. and Cochran, W.G. (1967) "Statistical Methods." 6 th Ed. Iowa State Univ. 


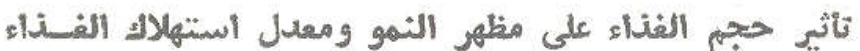

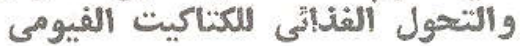 \\ محمد اببراهيم القطورى ك محمد جمال الدين قهر ، كمال عرفة يهنى ومحمد الهنداوى أمير كلية الزراعة - - جامعة القاهرة وبهامعة الزقازيق}

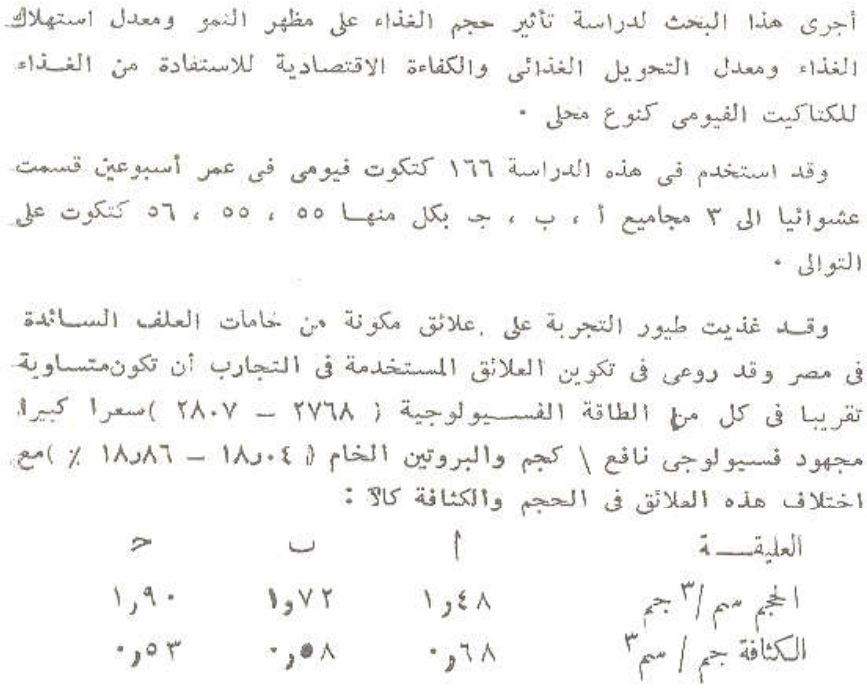

Egypt. J. Anim. Prod. 17, No. 1 (1977) 


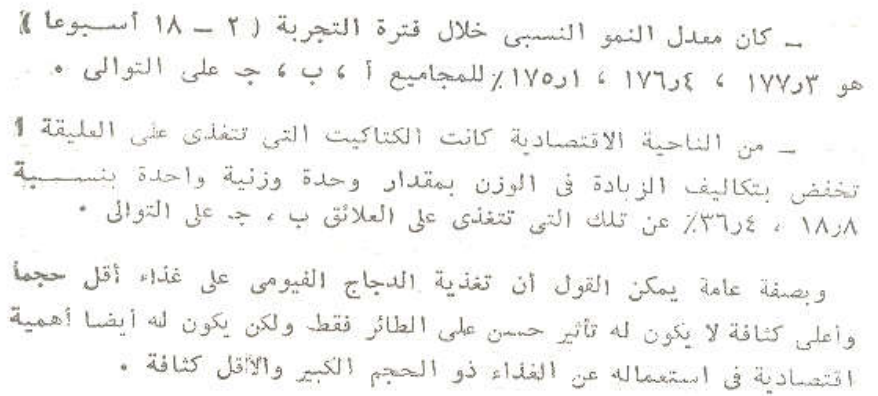

Egypt. J. Anim. Prod. 17, No. 1 (1977) 